\title{
EVALUATION OF CHEMICAL AND BACTERIOLOGICAL QUALITY OF RAW MILK FROM NEUDAMM DAIRY FARM IN NAMIBIA
}

Bille PG* ${ }^{1}$; Haradoeb BR $^{1}$ and N Shigwedha ${ }^{1}$

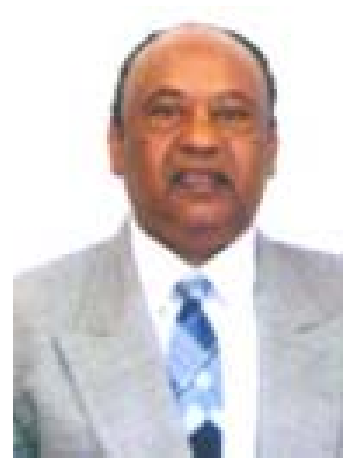

Bille Peter

*Corresponding author email: pbille@unam.na and nshigwedha@unam.na

${ }^{1}$ Department of Food Science and Technology, University of Namibia, Neudamm Campus, Private Bag 13301, Windhoek, Namibia. 


\section{ABSTRACT}

The quality of raw milk obtained from Friesian (Holstein) cows at Neudamm dairy farm was investigated after the quality issue was raised by some milk consumers at the University of Namibia, Neudamm campus. Some consumers complained about the short shelf-life of the milk as it is sold untreated due to lack of processing facilities at the centre. Others were worried of their health as they usually ferment raw milk for home use. In addition, the farm has no proper records of the quality of its milk for dairy herd management. The Department of Food Science and Technology of the University of Namibia, Neudamm campus took an initiative to identify the cause of the problems and the consumers' health concerns in order to come up with some remedial solutions. Samples for proximate composition and microbiological analyses were collected during the winter and summer seasons and from morning and evenings' milk at Neudamm Dairy Farm for chemical and microbial analyses. The quality of raw milk sold to staff members was evaluated and the data were used to assist the farm with dairy herd management programme and quality assurance. The mean temperatures, chemical, microbiology and acidity tests were determined. The temperatures ranged from 35 to $37^{\circ} \mathrm{C}$. Titratable acidity expressed as lactic acid had a mean of $0.18 \%$, total protein $3.2 \%$, fat $3.63 \%$, total solids (TS) $12.33 \%$; solids-not-fat (SNF) $8.7 \%$ and $\mathrm{pH}$ varied from 6.0 to 6.7. There were some variations in composition between winter and summer and between morning and evening milk, which are well known and significant at $\mathrm{p}<0.05$. Furthermore, large variations were noted in microbiological composition of raw milk with total aerobic counts ranging from $7.8 \times 10^{4}-1.3 \times 10^{6} \mathrm{cfu} / \mathrm{ml}$, coliforms from $2.4 \times 10^{2}-2.3 \times 10^{3} \mathrm{cfu} / \mathrm{ml}$ and lactic acid bacteria (LAB) from $1.2 \times 10^{3}-2.6 \times 10^{5} \mathrm{cfu} / \mathrm{ml}$. Yeasts and moulds were less than $100 \mathrm{cfu} / \mathrm{ml}$ in all samples analyzed. From the bacteriological and chemical analysis, it is concluded that the university farm needs a processing unit to control the quality of milk, add value and for training purpose.

Key words: Chemical, bacteriological, milk, quality, production 


\section{INTRODUCTION}

Milk from a healthy udder contains very few numbers of bacteria $\left(<3 \times 10^{4} \mathrm{cfu} / \mathrm{ml}\right)$ but may become contaminated by microorganisms from the surrounding environment during milking and milk handling, from water and milk equipments [1]. Dairy products quality defects have been attributed to poor microbiological quality of raw milk and heat-resistant enzymes [2,3]. The production of high quality milk should therefore be priority for good quality end products of long shelf life and for marketing of value added products. This is generally not easy to achieve in developing countries due to factors such as poor hygiene and sanitation during milking and milk handling, unclean water, high ambient temperatures, lack of cooling facilities and inadequate infrastructures for milk transportation to the processing facilities $[4,5]$.

Neudamm college dairy farm was owned by the Ministry of Agriculture, Water and Forestry of Namibia until last year (2008) and has now been taken over by the management of the University of Namibia, Faculty of Agriculture and Natural Resources. The farm is situated about $40 \mathrm{~km}$ east of Windhoek on the highway to Gobabis town and about $10 \mathrm{~km}$ to Hosea Kutako International Airport. The farm is located on a 1200 ha of arid rangeland with beef and dairy cattle, goats, sheep and with a few pigs and local chicken. The dairy herd totaling 53 cows of black and white Holstein-Friesian breeds (Bos Taurus) of which 7-9 are lactating and produce between $230-240 \mathrm{~kg}$ of milk per day. The harvesting of milk is carried out in a herringbone parlor using milking machine. Milk is sold to staff members directly after milking while warm $\left(35-37^{\circ} \mathrm{C}\right)$, as the batch cooler is slow, and at a subsidized price. Excess milk is skimmed off and the skim milk is distributed to the homes of destitute children and the elderly for free. At present there are no facilities available to process the milk except for cream separation and for the manufacture of farm butter. As an agricultural institution of higher learning, a pilot plant to convert the raw milk into some value added products would be ideal for training and for providing safe and alternative products to the community at Neudamm.

The quality of raw milk and the ability for the breed to produce milk to their potential are vaguely known at the farm and cows are provided with concentrates irrespective of their potentiality. At times milk quality deteriorates before it is consumed due to lack of quick cooling facility like surface cooler. The cows are grazed and fed on hay and silage and are supplemented with concentrates during milking. There is no evidence available at the farm to show the composition and microbiological quality of the milk for consumers' confidence and safety and for dairy herd management and training except for the quantities produced per cow and per day.

The objectives of this study were therefore to determine the chemical and microbiological quality and quantities of raw milk produced at the Neudamm dairy farm for value addition, safety, shelf-life and dairy herd management and for future development into a dairy pilot plant for training of workers and agricultural graduate students at the institute.

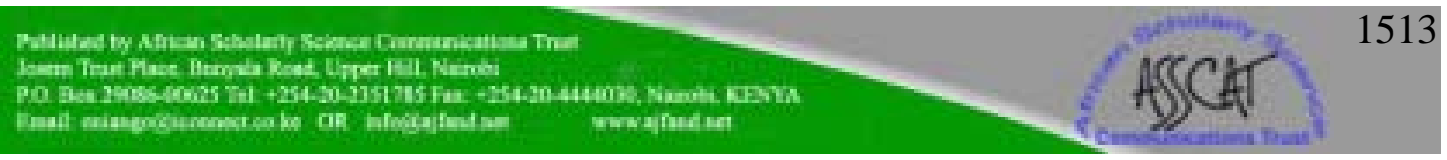




\section{MATERIALS AND METHODS}

\section{Materials}

Raw milk was obtained from 9 Friesian dairy cows at Neudamm farm in screw-cap $500 \mathrm{ml}$ sterile bottles and transported in ice-cooler to laboratory for analysis $[6,7]$. Nine samples from bulk milk with three replicates were collected in the morning and evening over winter (May-September) and summer (October-April) periods of 2006/7. The chemical analyses and microbiological counts were carried out within $3 \mathrm{~h}$ of sample collection at the University of Namibia, Neudamm Campus, in the Department of Food Science and Technology laboratory.

\section{Methods}

\section{Chemical characteristics of raw milk from Neudamm dairy farm}

The raw milk was analyzed for temperature, fat, total solids (TS), solids-not-fat (SNF), titratable acidity expressed as lactic acid and $\mathrm{pH}$. Temperatures were determined by a dairy thermometer, fat content was determined by the Gerber technique and total nitrogen by the Kjeldahl procedure. Crude protein was calculated by multiplying total nitrogen by a factor of 6.38 [8]. The oven drying method was used to determine the TS content of raw milk [9]. SNF values were obtained by subtracting the fat content from TS values. The $\mathrm{pH}$ of the samples was measured using a calibrated $\mathrm{pH}$ meter with a standard glass electrode. Acidity was determined by titration using the method of Case et al. [10]. Protein stability was determined by Resazurin, Clot-On-Boiling and 68\% Alcohol tests.

\section{Enumeration of bacteria, yeasts and molds}

Various microbiological counts were enumerated from each sample of raw milk. Ten $\mathrm{ml}$ of milk was diluted in $90 \mathrm{ml}$ of sterile Ringer's solution and mixed thoroughly. One ml of sample was serially diluted using sterile quarter-strength Ringer's solution and appropriate dilutions were plated using pour-plate method, as described by Harrigan and McCance, [11]. Total aerobic counts were obtained on Eugon's Agar (Oxoid, Unipath Ltd, Hampsshire, England), while lactic acid bacteria (LAB) counts were carried out on de Man, Rogosa and Sharpe (MRS) Agar with anaerobic incubation at $30 \pm 1^{\circ} \mathrm{C}$ for $48 \mathrm{~h}$. Coliform counts were carried out on Red Bile Agar incubated at $37 \pm 1^{\circ} \mathrm{C}$ for $24 \mathrm{~h}$. Confirmation of the presence of coliform was done in $2 \%$ Brilliant Green Bile Broth with inverted Durham tubes at $45^{\circ} \mathrm{C}$. Evolution of gas and production of acid were considered as positive results for coliforms. Rose-Bengal Chloramphenicol Agar was used for the enumeration of yeasts and moulds. The plates were incubated aerobically at $25^{\circ} \mathrm{C}$ for 5 days.

\section{Statistical analyses}

All determinations were carried out in triplicates. Mean values and standard deviations were calculated. Analysis of Variance (ANOVA) was also performed and separation of the mean values was carried out by Duncan's Multiple Range Test at $\mathrm{p}<0.05$ using Statistical Package for Social Sciences (SPSS) software, version 10.0.

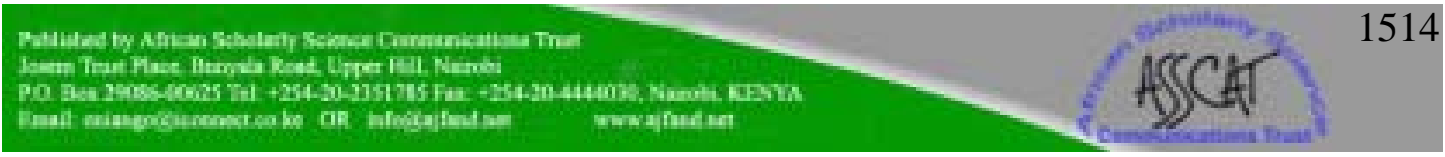




\section{RESULTS}

\section{Chemical characteristics of winter, summer, morning and evening milk}

The chemical characteristics of the raw milk samples obtained from Neudamm dairy farm are summarized in Tables 1 and 5.

The temperature of milk ranged from 35 to $37^{\circ} \mathrm{C}$. Fat content ranged from 2.9 to $4.6 \%$, with seven samples containing above South Africa (SANS) regulated minimum standard of $3.3 \%$ fat [12]. Total solids (TS) content ranged from 10.64 to $13.41 \%$, while the Solid-Not-Fat (SNF) fraction ranged from 8.09 to $9.03 \%$ (Table 1). The SNF in two samples were below the stipulated minimum value of $8.5 \%$, whereas four samples recorded below the TS minimum of $11.6 \%[10,12]$. Density or specific gravity of the raw milk ranged from 1.029 to 1.033 which was within the SA regulated minimum standard (SABS) of 1.028 .

Results of Resazurin, Clot-on-boiling and Alcohol tests on the milk samples were fairly good but deteriorated fast when purchased and stored in consumers' containers without cooling. The Resazurin test disc numbers ranged from 3-6 which indicated fair to excellent milk quality while alcohol and clot-on-boiling tests showed that the milk was of fairy good quality at the selling point.

Results of crude protein (Table 1) in some instances were lower than normal average values for cow's milk, i.e. $2.84 \%$ as opposed to $3.2 \%$. Table $2 \& 3$ show clearly that there are significant differences $(\mathrm{p}<0.05)$ between the quality of winter and summer milk and also between morning and evening milk. The seasonal differences in proximate composition existed in fat, TS and SNF including the density. High fat content tends to reduce the density of milk as it has a lower density of 0.93 compared to that of whole milk which is $1.032 \mathrm{~g} / \mathrm{cm}^{3}$. There were also significant differences $(\mathrm{p}<0.05)$ between evening and morning milk yield per cow (Table 3). The mean difference ranged from $8 \mathrm{~kg}$ to $18 \mathrm{~kg}$ respectively.

The $\mathrm{pH}$ values and acidities of some of the samples were in the range of 6.0 to 6.59 and 0.15 to $0.21 \%$ respectively. These figures were slightly out of the South Africa mean standard range of $\mathrm{pH} 6.5$ to 6.7 and acidity of 0.14 to $0.17 \%$ LA [12].

\section{Microbiological characteristics}

The counts of bacteria, yeasts and moulds from raw milk of Neudamm dairy farm are summarized in Table 4.

The total aerobic counts of Neudamm farm milk ranged from $7.8 \times 10^{3}-1.3 \times 10^{5}$ colony forming units $(\mathrm{cfu} / \mathrm{ml})$ with seven (7) of the nine (9) samples having less than $10^{5} \mathrm{cfu} / \mathrm{ml}$. These were below the South Africa Microbiological Standards (SANS) [12] for grade A milk of $1 \times 10^{5}$ and $6 \times 10^{5} \mathrm{cfu} / \mathrm{ml}$ for grade B milk. Lactic acid bacteria $(\mathrm{LAB})$ ranged from $1 \times 10^{3}$ to $2.6 \times 10^{4} \mathrm{cfu} / \mathrm{ml}$. These figures are, however, below the SANS or South Africa Bureau of Standard but the farm needs to watch out for mastitis, sanitation and hygiene, especially since the cooling facility is not

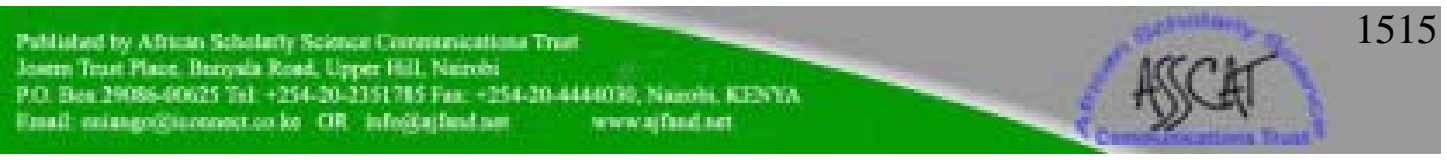


efficient. The lactic acid bacteria and total aerobic counts were equal in numbers but lower than those reported from other African countries [13].

Coliforms ranged from $2.4 \times 10^{2}$ to $2.3 \times 10^{3} \mathrm{cfu} / \mathrm{ml}$. The presence of high numbers of coliforms in milk provides an index of hygienic standard used in the production of milk, as unclean udder and teats can contribute to the presence of coliforms from a variety of sources such as manure, soil, feed, personnel and even water $[14,15]$.

Yeasts and moulds were less than $100 \mathrm{cfu} / \mathrm{ml}$ in five samples and were not found in four samples analyzed. This was expected as most contamination is usually bacterial in this kind of environment where machine milking is used.

\section{DISCUSSION}

Temperature, chemical composition and total aerobic counts are usually used to determine the overall hygiene, sanitation, quality and storage conditions of raw milk. In some countries, including China [16], the total aerobic counts are used as a means to grade milk for quality payment and to encourage the production of high quality raw milk. This also helps to enhance the overall hygienic standards during milking and handling, otherwise producers of milk below the set standards are penalized and those who produce better quality milk are given bonuses.

Since milk at Neudamm dairy farm is distributed locally to consumers untreated and warm at the temperature ranging from $35-37^{\circ} \mathrm{C}$, there is likelihood of the milk deteriorating with time before it is consumed. This could be the reason that some consumers complained that the milk was of poor quality and sometimes clotted on heating. However, the alcohol test, clot-on-boiling test and resazurin test (protein stability tests) which were carried out on the suspected samples indicated that they were still acceptable (Lovibond Disc Comparator Numbers 3-6), but with short shelf life as was sold without cooling. It was also observed that some of the suspected samples which were lower in $\mathrm{pH}$ values did not necessarily have corresponding higher acidities. This phenomenon could partly be explained by variations in the chemical composition of the milk and other management factors. Crude protein (nitrogen $\mathrm{x}$ 6.38) showed results which were generally lower than the normal average values for cow's raw fresh milk (3.2 to 3.3\%). The gross composition of raw milk could be affected by several factors which may include breed of cows (Holstein-Friesian), stage of lactation, feeding, environmental stress, seasonality and adulteration as well as the age of the cows, though these factors were not fully monitored in this study [14].

The phenomenon at Neudamm milk may have been attributed to feeds, since cattle are fed with dry fodder like hey and concentrates in winter and green pastures in rainy summer season in Namibia. Changes of temperatures may also affect fluctuation of fat content since Namibia can be really hot in summer with temperature ranging from 35 to $38^{\circ} \mathrm{C}$ [13]. The fat content of milk decreases as the weather becomes warmer and increases again with the approach of winter $\left(+15\right.$ to $\left.-5^{\circ} \mathrm{C}\right)$. The TS and SNF contents

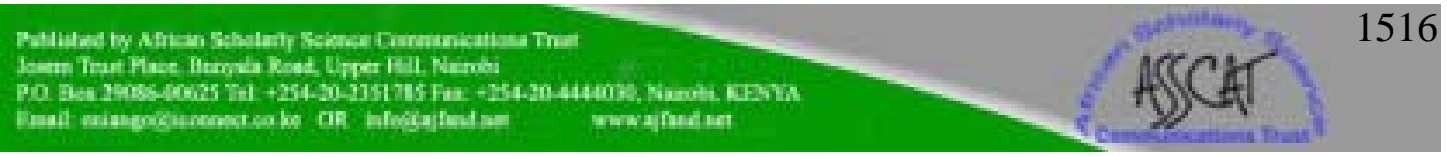


of the milk generally follow the variation of the fat content, the higher the fat content the higher are the TS and SNF [13] but lower the density. Similarly, morning milk has higher contents of milk constituents compared to evening milk as described by Lampert [17] and this can range from 0.5 to $2.0 \%$ more fat in morning milk. The ANOVA analysis indicated that there were significant differences between morning and evening milk at $\mathrm{p}<0.05$ in fat, TS, SNF contents and density at the milking stage as well as milk production per cow as shown in Tables 2 and 3. The mean production difference ranged from $8 \mathrm{~kg}$ to $18 \mathrm{~kg}$ respectively and this could be attributed to the longer resting period at night or between milking and at this stage most of the energy is conserved for milk synthesis rather than for movement of cows searching for pastures.

High numbers of bacteria may be associated with unclean udder, teats and unclean storage tank $[1,6]$. In addition, lactic acid bacteria (LAB) may grow and produce acid that may spoil the milk if not cooled. The LAB figures are however, below the SABS but the farm needs to watch out for mastitis, sanitation and hygiene especially since there is no fast cooling facility. However, the LAB and total aerobic counts were lower than those reported from other African countries [13, 14], which indicate that Neudamm dairy farm is practicing a reasonably good sanitation and hygienic standards with fairly good bacteriological quality.

The presence of high numbers of coliforms in milk provides an index of hygienic standard used in the production of milk, as unclean udder and teats can contribute to the presence of coliforms from various sources such as manure, soil, feed, personnel and water $[15,16,17]$. Higher number of coliforms is of public concern as may carry serious pathogenic coliforms such as E. coli, Salmonella, Shigella spp. etc. One Salmonella organism in $100 \mathrm{ml}$ of contaminated milk may result in human infection and diseases [18]. These coliforms may have originated from the feeds such as concentrates and hey or dry grass, personnel and water.

\section{CONCLUSION}

There were some variations in chemical composition of Neudamm farm milk. The fat content of some samples was below the required minimum standards [12]. The total aerobic and LAB counts were within the minimum acceptable range but could be improved with better sanitation, hygiene and milk cooling. Of particular concern were the high coliform counts, which suggested poor hygienic standards during milking, milk handling and milk containers. High microbial counts and the possible rapid multiplication are likely to affect the keeping quality of the raw milk sold directly to consumers without processing and cooling [2]. The current lower chemical characteristics of Neudamm milk can be improved by mixing or crossing the breeds or by changing the breeds to Jerseys or Guernseys. The quality of raw milk distributed to consumers should be improved by observing HACCP concepts including proper sanitation and hygiene and should be processed, cooled to $4-5^{\circ} \mathrm{C}$ and packaged before distribution. A pilot plant could be ideal for this as it is not that expensive. The bacteriological and chemical quality of raw milk are the basis for the quality of end

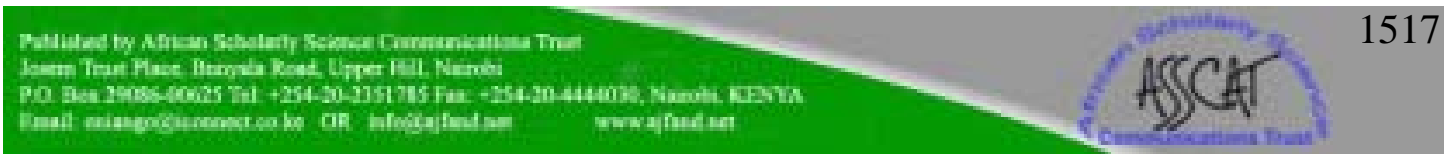


dairy products $[2,13]$ and therefore the production of high quality milk should be of great importance to the economy of the farm and future sustainable development of a pilot plant at the dairy.

\section{RECOMMENDATION}

The management of the Neudamm dairy farm as a matter of urgency and for public health safety should consider purchasing processing equipments to control quality of milk from deterioration and to add value. It should also consider increasing the quantities of milk from the current $230-240 \mathrm{~kg}$ of milk per day from 9 lactating cows to at least $500 \mathrm{~kg}$ per day from the 53 dairy herds available on the farm. This will justify the purchase of a pilot plant in order to eliminate milk quality problems, train the workers and graduate students of animal and food science and technology on the basics of milk production and handling. It would also allow processing of value added products such as pasteurized milk, table cream, butter and fermented milk products such as cheese, yoghurt and sour milk (Omaere) for income generation and for Neudamm community, who are situated $40 \mathrm{~km}$ away from the nearest town or shopping centre.

\section{ACKNOWLEDGEMENT}

The authors wish to thank dairy farm manager and his colleagues for their willingness to assist with milk samples and for providing useful information and Mr. Jonazi, a Faculty statistician for statistical guidance and analyses. We would also like to thank librarians for their assistance in providing useful materials and finally, we would like to express our appreciation to other staff members of the faculty especially the Principal of the college Dr. A. Rothauge, for accepting the contents of the manuscript. 
Table 1: Means proximate composition (\%), titratable acidity (\%), pH and density of 7 samples of raw milk

\begin{tabular}{lccc}
\hline Attributes & Minimum & Maximum & Mean \pm SD \\
\hline Fat & 2.50 & 4.60 & $3.45 \pm 0.37$ \\
Protein & 2.84 & 3.49 & $3.17 \pm 0.65$ \\
TS & 10.64 & 13.41 & $11.96 \pm 0.53$ \\
SNF & 8.09 & 9.03 & $8.40 \pm 0.54$ \\
pH & 6.00 & 6.59 & $6.52 \pm 0.32$ \\
Acidity & 0.15 & 0.21 & $0.19 \pm 0.02$ \\
Density $\dagger$ & 1.03 & 1.03 & $1.03 \pm 0.03$ \\
\hline Density; g/cm3 & & &
\end{tabular}

Table 2: Summary of chemical characteristics (\%) and pH values of 7 samples of raw milk collected from Neudamm dairy farm in 2007/8

\begin{tabular}{lcccc}
\hline Attributes & Winter & Summer & Morning & Evening \\
\hline pH & $6.65 \pm 0.23$ & $6.12 \pm 0.23$ & $6.54 \pm 0.23$ & $6.48 \pm 0.23$ \\
Titratable acidity & $0.15 \pm 0.02$ & $0.19 \pm 0.02$ & $0.17 \pm 0.02$ & $0.18 \pm 0.02$ \\
Fat & $4.10 \pm 0.45$ & $3.20 \pm 0.45$ & $4.12 \pm 0.45$ & $3.56 \pm 0.45$ \\
SNF & $9.00 \pm 0.34$ & $8.40 \pm 0.34$ & $8.98 \pm 0.34$ & $8.41 \pm 0.34$ \\
TS & $13.10 \pm 0.77$ & $11.60 \pm 0.77$ & $13.10 \pm 0.77$ & $11.97 \pm 0.77$ \\
Density $\dagger$ & $1.03 \pm 0.001$ & $1.032 \pm 0.001$ & $1.032 \pm 0.001$ & $1.032 \pm 0.001$ \\
\hline Note: $\dagger$ Density is express as g/cm3, \pm Standard deviation. Titratable acidity expressed as \% lactic acid \\
\multicolumn{4}{r}{ SNF = Solids-Not-Fat, TS = Total Solids, Values are mean \pm SD for seven determinations }
\end{tabular}


Table 3: Morning and evening mean milk production per cow $(\mathrm{Kg} \pm \mathrm{SD})$

\begin{tabular}{lccc}
\hline Cow number & Morning milk & Evening milk & Yields/day \\
\hline F 146 & $16 \pm 1.07$ & $9 \pm 0.82$ & $25 \pm 1.89$ \\
F 112 & $18 \pm 0.69$ & $8 \pm 0.82$ & $26 \pm 1.82$ \\
F 125 & $17 \pm 0.58$ & $6 \pm 0.62$ & $23 \pm 1.20$ \\
F 140 & $19 \pm 1.15$ & $8 \pm 0.58$ & $27 \pm 1.73$ \\
F 132 & $14 \pm 0.82$ & $9 \pm 0.82$ & $23 \pm 1.64$ \\
F 133 & $18 \pm 0.82$ & $8 \pm 0.58$ & $26 \pm 1.40$ \\
F 150 & $23 \pm 0.90$ & $9 \pm 0.82$ & $32 \pm 1.72$ \\
F 154 & $19 \pm 1.16$ & $9 \pm 0.82$ & $28 \pm 1.98$ \\
F 150V & $14 \pm 1.29$ & $10 \pm 1.29$ & $24 \pm 2.58$ \\
\hline Total production per day: $234 \mathrm{Kg}=$ Mean $26 \mathrm{~kg} / \mathrm{cow}$
\end{tabular}

Table 4: Means of minimum and maximum microbial counts in 7 samples of raw milk with three replicates $(\mathrm{cfu} / \mathrm{ml})$

\begin{tabular}{lcc}
\hline Microbes & Minimum & Maximum \\
\hline Total aerobic counts & $7.8 \times 10^{3}$ & $1.3 \times 10^{5}$ \\
Lactic acid bacteria & $1.0 \times 10^{3}$ & $2.6 \times 10^{4}$ \\
Coliforms & $2.4 \times 10^{2}$ & $2.3 \times 10^{3}$ \\
Yeasts and moulds & $<100$ & $<100$ \\
\hline cfu/ml - colony forming unit per ml &
\end{tabular}


Table 5: Results of Resazurin, Clot-On-Boiling and Alcohol tests or Protein stability tests

\begin{tabular}{lcccc}
\hline Attributes & Winter & Summer & Morning & Evening \\
\hline 10 min Resazurin test & $4-5$ & $3-4$ & $5-6$ & $4-5$ \\
Clot-On-Boiling Test & $-\mathrm{ve}$ & $\pm \mathrm{ve}$ & $-\mathrm{ve}$ & $\pm \mathrm{ve}$ \\
68\% Alcohol Test & $-\mathrm{ve}$ & $-\mathrm{ve}$ & $-\mathrm{ve}$ & $-\mathrm{ve}$ \\
\hline
\end{tabular}

Note: Resazurin Disc No: 3-4 = fair to good milk; 4-5 = good to very good milk; 5-6 $=$ very good to excellent milk. Clot-On-Boiling: $-\mathrm{ve}=$ very good milk; $\pm=$ good to fair milk; $68 \%$ Alcohol test: All were -ve = good milk. 


\section{REFERENCES}

1. Cousins CM and AJ Bramley The Microbiology of Raw Milk. In: Robinson RK (Eds.), Dairy Microbiology Vol. 1, Applied Science Publishers, UK. 1981: 119-163.

2. Marshall RT Relationship between the bacteriological quality for raw milk and the final products. A review of basic information and practical aspects. Kieler Milchwirtchaftliche Forschungsberichte.1982; 34: 149-157.

3. Muir DD, Griffiths WM, Phillips JD, Sweetsur AWM and IG West Effect of bacterial quality of raw milk on bacterial quality and some other properties of low-heat and high-heat dried milk. J. Soc. Dairy Technol. 1986; 39: 115-118.

4. Berg JCT Dairy Technology in the Tropics and Subtropics. Pudoc Publishers, Wageningen, the Netherlands. 1988. ISBN 90-220-0927-0

5. Bille PG, Vovor MN, Goreseb $\mathbf{J}$ and EL Keya Evaluating the possibility of adding value to goat's milk by producing yoghurt using low cost technology method for rural Namibia. The J. Food Tech in Africa. 2000; 5: 130-144.

6. IDF. Factors influencing the bacteriological quality of raw milk. Int. Dairy Federation Bulletin No. 120. Int. Dairy Federation, Brussels, Belgium, 1980.

7. IDF. Milk and Milk Products: Methods of sampling. Int. Dairy Federation, Brussels, Belgium. 1985.

8. Egan H, Kirk RS and R Sawyer Pearson's Chemical analysis of Foods. $8^{\text {th }}$ edn. Churchill Livingstone. Edinburgh, UK. 1981.

9. AOAC. Official Methods of Analysis. $16^{\text {th }}$ Edn. Cambridge University Press. 1995.

10. Case RA, Bradley JR and RR Williams Chemical and Physical Methods. In G.H. Richardson (ed), Standards Methods for the Examination of Dairy Products APHA, $15^{\text {th }}$ edn., Washington D.C., USA. 1981; 327-404.

11. Harrigan WF and ME McCance Laboratory Methods in Food and Dairy Microbiology. Academic Press Ltd. London, UK. 1976.

12. SANS ISO/IEC. $\mathbf{4 8 3 2}$ Microbiology of Food and Animal Feeding Stuff. South African Bureau of Standards. 2006.

13. Abd El-Ghani S On bacterial quality of raw market milk in rural areas of Giza Province. Egyptian Journal of Food Science 1993; 21: 73-77. 
14. Connolly B and B O'Brien Milk quality for processing: Breeding, Feeding and Milking Management to Ensure Good Quality Milk for Manufacturing. $24^{\text {th }}$ Int. Dairy Congress, Melbourne, Australia. 1995.

15. Thomas SB, Druce RG and M Jones Influence of Production Conditions on Bacteriological Quality of refrigerated farm bulk milk - A review. J. App. Bacteriol., 1971; 34: 659-677.

16. Chinese Center for Disease Control and Prevention (CDC) Compilation of Hygienic Standards for Food of China. Beijing: Chinese Standard Press. 1998.

17. Lampert LM Modern Dairy Products. $3^{\text {rd }}$ Edn., Chemical Publishing Company, Inc. New York, USA. 1975.

18. Fountaine RE, Cohen ML, Martin WT and TM Vernon Epidemic of Salmonellosis from cheddar cheese: surveillance and prevention. AM. J. Epidemiol., 1980; 111: 247-253. 